\title{
Korelasi antara Kadar Neutrophil Gelatinase Associated Lipocaline Urin dengan Laju Filtrasi Glomerulus pada Variasi Waktu untuk Mendeteksi Dini Gangguan Ginjal Akut pada Anak Sepsis
}

\author{
Anggun Sri Mardhika, Dadang Hudaya Somasetia, Diah Asri Wulandari \\ Departemen Ilmu Kesehatan Anak Fakultas Kedokteran Universitas Padjadjaran/RSUP Dr Hasan Sadikin, Bandung
}

Latar belakang. Sepsis dapat menimbulkan gangguan fungsi ginjal. Neutrophil gelatinase associated lipocaline urine (NGALu) merupakan penanda biologis baru lebih cepat dibandingkan laju filtrasi glomerulus (LFG) untuk deteksi dini gangguan ginjal akut (GgGA). Kadar NGALu pada anak sepsis dapat meningkat pada jam ke-0, 12, 24, dan 48. Belum ada penelitian mengenai korelasi antara kadar NGALu dengan LFG pada variasi waktu untuk mendeteksi dini GgGA pada anak sepsis.

Tujuan. Mengetahui korelasi kadar NGALu dengan LFG pada variasi waktu untuk mendeteksi dini GgGA pada anak sepsis.

Metode. Metode penelitian potong lintang. Subjek penelitian anak sepsis di unit gawat darurat, instalasi rawat inap, High Care Unit (HCU), dan Pediatric Intensive Care Unit (PICU) Rumah Sakit Dr. Hasan Sadikin bulan Mei 2017-Februari 2018. Pemeriksaan kreatinin dan NGALu dilakukan pada variasi waktu jam ke-0, 12, 24, dan 48. Analisis bivariabel menggunakan uji korelasi Spearman. Hasil. Penelitian mengikutsertakan 23 anak sepsis. Pada jam ke-24 nilai NGALu dan LFG berturut-turut 60,30 ng/ml, 128,33 ml/ $\mathrm{min} / 1,73 \mathrm{~m} 2$. Terdapat korelasi yang bermakna antara NGALu dengan LFG pada variasi waktu jam ke-24 dengan nilai $\mathrm{p}=0,000 \mathrm{dan}$ korelasi negatif sedang dengan $\mathrm{r}=-0,668$.

Kesimpulan. Terdapat korelasi antara kadar NGALu dengan LFG pada variasi waktu jam ke-24 untuk mendeteksi dini GgGA pada anak sepsis. Sari Pediatri 2019;21(1):1-7

Kata kunci : anak sepsis, LFG, NGALu, gangguan ginjal akut

\section{Correlation of Urinary Neutrophil Gelatinase Associated Lipocaline Levels and Glomerular Filtration Rate at The Times Variation for Early Detection of Acute Kidney Injury in Children With Sepsis}

\begin{abstract}
Anggun Sri Mardhika, Dadang Hudaya Somasetia, Diah Asri Wulandari
Background. Sepsis can cause kidney dysfunction. Urinary Neutrophil Gelatinase-Associated Lipocaline (uNGAL) is now a new biological marker faster than Glomerular Filtration Rate (GFR) for early detection of Acute Kidney Injury (AKI). uNGAL levels of children with sepsis can increase at the variation of $0,12,24$, and 48 hours. There has been no research on the correlation between uNGAL levels and GFR at the times variation for early detection AKI in children with sepsis.

Objective. To know the correlation between uNGAL levels and GFR at the times variation for early detection AKI in children with sepsis.

Methods. The method used is a cross-sectional study. Research subjects are children with sepsis in the emergency room, ward, High Care Unit (HCU), and Pediatric Intensive Care Unit (PICU) of Dr. Hasan Sadikin Hospital from May 2017 to February 2018. Creatinine and uNGAL are examined at the variation of $0,12,24$, and 48 hours. Spearman Correlation Test is used for bivariable analysis.

Result. This study includes 23 children with sepsis. At the hour of-24 the value of NGALu and GFR were $60.30 \mathrm{ng} / \mathrm{ml}, 128.33 \mathrm{ml} /$ $\mathrm{min} / 1.73 \mathrm{~m} 2$. There is a significant correlation between uNGAL and GFR at 24 hours with $\mathrm{p}=0,000$ and medium negative correlation with $\mathrm{r}=-0,668$.

Conclusion. There is a correlation between uNGAL levels and GFR at 24 hours for early detection AKI in children with sepsis. Sari
\end{abstract} Pediatri 2019;21(1):1-7

Keywords: children with sepsis, GFR, uNGAL, acute kidney injury

Alamat korespondensi: Anggun Sri Mardhika. Departemen Ilmu Kesehatan Anak Fakultas Kedokteran Universitas Padjadjaran/RSUP Dr Hasan Sadikin Bandung, Indonesia. Jalan Pasteur No 38 Bandung 40151. E-mail: anggun204@gmail.com 
S epsis masih merupakan masalah global karena mempunyai angka kejadian yang tinggi, tata laksana yang rumit, mortalitas yang tinggi, dan biaya perawatan yang mahal. ${ }^{1}$ Insiden sepsis pada anak terus meningkat dan merupakan penyebab utama kematian di seluruh dunia. ${ }^{2}$ Sepsis didefinisikan sebagai disfungsi organ yang mengancam kehidupan yang disebabkan oleh disregulasi imun terhadap infeksi. ${ }^{3}$ Penapisan sepsis dini dapat dilakukan dengan menggunakan skor quick sequensial organ faillure assesment score (qSOFA), quick pediatric logistic organ dysfunction (qPELOD-2), dan untuk disfungsi organ menggunakan skor PELOD-2. ${ }^{4}$ Salah satu tanda klinis sepsis adalah hipotensi yang terjadi apabila tubuh sudah tidak bisa mengompensasi kebutuhan jaringan termasuk perfusi ginjal yang menyebabkan terjadinya gangguan ginjal akut (GgGA). ${ }^{5}$ Sepsis pada dewasa dan anak dapat menyebabkan GgGA 40\%-50\%. ${ }^{6}$ Sepsis merupakan salah satu penyebab sakit kritis pada anak dan merupakan penyebab utama terjadinya GgGA.7,8

Ginjal merupakan organ ekskresi tubuh yang berfungsi menjaga keseimbangan internal dengan jalan menjaga komposisi cairan ekstrasel. ${ }^{7}$ Ginjal dapat mengalami gangguan sehingga proses filtrasi zat toksis tidak berjalan maksimal bahkan ada kalanya terjadi gagal ginjal. ${ }^{9}$ Gangguan ginjal akut merupakan istilah pengganti dari gagal ginjal akut, didefinisikan sebagai penurunan mendadak fungsi ginjal dengan penilaian laju filtrasi glomerulus (LFG), ditandai dengan peningkatan kadar kreatinin serum dan hasil metabolisme nitrogen serum lainnya serta adanya ketidakmampuan ginjal untuk mengatur homeostasis cairan dan elektrolit. ${ }^{7}$ Kriteria GgGA dibuat berdasarkan pediatric risk injury failure loss end stage renal disease ( $\mathrm{pRIFLE)} \mathrm{yang} \mathrm{dinilai} \mathrm{dari} \mathrm{kriteria}$ LFG dan kriteria luaran urin. ${ }^{7}$

Gangguan ginjal akut secara global telah menjadi tantangan utama kesehatan dengan perkiraan 13,3 juta kasus per tahun dan menyebabkan kematian 1,7 juta kasus per tahun. ${ }^{8}$ Berdasarkan 7 th Report of Indonesian Renal Registry pada tahun 2014, angka kejadian gagal ginjal akut pada anak dan dewasa di Indonesia tercatat 1562 pasien. ${ }^{10}$ Gangguan ginjal akut ini dapat didiagnosis dengan pemeriksaan parameter urinalisis, blood urea nitrogen (BUN), kadar kreatinin serum, elektrolit, sistatin C, analisis gas darah sesuai indikasi, serta pemeriksaan neutrophil gelatinase associated lipocaline urine (NGALu). ${ }^{11}$
Neutrophil gelatinase associated lipocaline merupakan protein yang disintesis dan disekresi sel epitel tubulus dari segmen distal dan proksimal. Protein ini muncul dalam konsentrasi sangat rendah pada berbagai jaringan tubuh, termasuk ginjal, paru, dan traktus gastrointestinal, tetapi diproduksi oleh sel epitel yang mengalami jejas dalam jumlah yang meningkat. ${ }^{12}$ Kadar NGALu dan plasma meningkat cepat dan dini pada anak sepsis yang mengalami GgGA. Peningkatan NGALu sampai 100 kali lipat dibandingkan kadar NGAL plasma yang meningkat hanya 20 kali lipat. ${ }^{13}$ Dalam berbagai proses penyakit yang beragam, NGALu juga merupakan penanda biologis dini yang sangat sensitif, spesifik, dan bersifat prediktif. ${ }^{12}$

Pengukuran NGALu dapat menunjukkan timbulnya GgGA pada pasien anak di ruang rawat intensif lebih dini sekitar 2 hari sebelum terjadinya peningkatan kreatinin serum. ${ }^{14}$ Penelitian terhadap pasien anak dan dewasa sakit kritis menunjukkan kadar NGALu dan plasma dapat meningkat pada jam ke-0, 12, 24, dan 48. ${ }^{15,16}$ Puncak peningkatan kadar NGALu pada anak sakit kritis terjadi pada jam ke-6 sampai 12 sejak pasien masuk perawatan. ${ }^{17}$ Penelitian yang dilakukan di Rumah Sakit Dr. Hasan Sadikin (RSHS) pada tahun 2014 menunjukkan adanya peningkatan kadar NGALu dan kreatinin serum pada pasien anak sepsis berat. ${ }^{18}$

Para peneliti sebelumnya telah menganalisis korelasi antara kadar NGALu dengan LFG pada anak sakit kritis. Tujuan dari penelitian ini menganalisis korelasi antara kadar NGALu dengan LFG pada variasi waktu jam ke-0, 12, 24, dan 48 untuk mendeteksi dini GgGA pada anak sepsis.

\section{Metode}

Penelitian dilakukan pada bulan Mei 2017-Februari 2018 di RSHS Bandung. Subjek penelitian adalah anak sepsis dengan kriteria inklusi dirawat di unit gawat darurat, instalasi rawat inap, HCU, atau PICU, usia $\geq 1$ bulan-18 tahun, status gizi baik berdasarkan World Health Organization child growth standard (WCGS), orang tua/wali menyetujui untuk ikut serta dalam penelitian secara tertulis. Kriteria eksklusi adalah pasien dengan kelainan ginjal sebelumnya yang diketahui melalui anamnesis. Penapisan sepsis menggunakan qSOFA, dan qPELOD-2. 
Bentuk penelitian analitik observasional dengan rancangan penelitian jenis potong lintang. Variabel penelitian adalah NGALu, LFG, serta variabel perancu jenis kelamin, usia responden, dan tinggi badan. Ukuran sampel ditentukan berdasarkan uji statistik yang digunakan, yaitu mencari korelasi antara $\mathrm{x}$ dan $\mathrm{y}$, kemudian ditetapkan taraf kemaknaan 5\% dan power of the test $80 \%$ serta besarnya koefisien korelasi antara $x$ dan y dengan $r=-0,550$. Penelitian dilaksanakan setelah mendapat persetujuan dan rekomendasi dari Komite Etik Penelitian Kesehatan Fakultas Kedokteran Universitas Padjadjaran Rumah Sakit Dr. Hasan Sadikin Bandung Nomor : LB.04.01/A05/EC/160/V/2017.

Pemeriksaan NGALu dilakukan dengan pemasangan kateter. Pengambilan urin 5-10 mL dengan cara dialirkan dari kateter ke dalam wadah penampung, diberi label identitas dan disimpan dalam suhu $-20^{\circ} \mathrm{C}$ sebelum akhirnya diperiksa dengan kit R\&D menggunakan metode ELISA. Pengambilan darah dilakukan untuk pemeriksaan kreatinin serum. Darah diaspirasi sebanyak 3-5 mL, selanjutnya dimasukkan ke dalam tabung khusus dan diberi label identitas. Pemeriksaan kreatinin serum menggunakan mesin Cobas 6000. Nilai kreatinin digunakan untuk menghitung LFG dengan menggunakan rumus Schwartz.

Analisis data diuji dengan Shapiro Wilk, didapatkan data tidak berdistribusi normal. Selanjutnya dilakukan analisis korelasi antara kadar NGALu dan LFG pada variasi waktu jam ke-0, 12, 24, dan 48 dengan menggunakan uji korelasi Spearman.

\section{Hasil}

Selama penelitian didapatkan 190 anak sepsis. Tigapuluh enam subjek memenuhi kriteria, 13 dikeluarkan dari penelitian karena meninggal dunia sebelum selesai pengambilan sampel penelitian sehingga jumlah subjek yang diambil 23 anak sepsis. Karakteristik umum subjek penelitian tertera pada Tabel 1. Usia, jenis kelamin, dan tinggi badan tidak terbukti sebagai variabel perancu pada penelitian ini (nilai $\mathrm{p}>0,05$ ).

Tabel 2 menunjukkan karakteristik laboratorium subjek penelitian berdasarkan hasil kreatinin, LFG, dan kadar NGALu pada variasi waktu jam ke-0, 12, 24, dan 48.

Berdasarkan uji Shapiro Wilk didapatkan data tidak berdistribusi normal, sehingga dilakukan analisis korelasi antara kadar NGALu dan LFG pada variasi waktu jam ke-0, 12, 24, dan 48 dengan menggunakan uji korelasi Spearman.

Gambar 1 dan Tabel 3 menunjukkan korelasi kadar NGALu dengan LFG pada variasi waktu jam ke-0,

Tabel 1. Karakteristik umum subjek penelitian

\begin{tabular}{lccc}
\hline Variabel & $\begin{array}{c}\text { Jumlah } \\
\mathrm{n}=23\end{array}$ & $\begin{array}{c}\mathrm{p} \\
\text { (terhadap NGALu) }\end{array}$ & $\begin{array}{c}\mathrm{p} \\
\text { (terhadap LFG) }\end{array}$ \\
\hline Usia (tahun) & & & \\
$\quad$ Rerata $\pm($ Std) & $6,52 \pm(4,630)$ & & \\
Median (min-maks) & $7(1-14)$ & $\mathrm{p}=0,562$ & $\mathrm{p}=0,182$ \\
Jenis kelamin & $11(47,8 \%)$ & $\mathrm{p}=0,740^{*}$ & $\mathrm{p}=0,525^{*}$ \\
$\quad$ Laki-laki & $12(52,2 \%)$ & & \\
Perempuan & & & \\
Tinggi badan & $107,19 \pm(27,275)$ & & \\
Rerata \pm (Std) & $108(67-160)$ & $\mathrm{p}=0,612$ & \\
Median (min-maks) & & & \\
Kelainan penyebab rawat $(\%)$ & $14(60,9)$ & & \\
Hemato-onkologi & $4(17,4)$ & & \\
Neurologi & $2(8,7)$ & & \\
Gastrohepatologi & $1(4,3)$ & & \\
Kardiologi & $1(4,3)$ & & \\
Infeksi & $1(4,3)$ & & \\
Bedah anak & & & \\
\hline
\end{tabular}

Keterangan: Data kategorik disajikan dengan jumlah/frekuensi dan persentase sedangkan data numerik disajikan dengan rerata, median, dan standar deviasi. $\mathrm{p}=$ signifikansi $(\mathrm{p}<0,05)$. Tanda *: berdasarkan uji Mann Whitney 
Tabel 2. Karakteristik laboratorium subjek penelitian

\begin{tabular}{lcccc}
\hline Variabel & \multicolumn{4}{c}{ Waktu pengukuran } \\
\cline { 2 - 5 } & Jam ke-0 & Jam ke-12 & Jam ke-24 & Jam ke-48 \\
\hline Kreatinin $(\mathrm{mg} / \mathrm{dl})$ & $0,65 \pm(0,579)$ & $0,74 \pm(0,713)$ & $0,71 \pm(0,621)$ & $0,66 \pm(0,489)$ \\
Rerata $\pm(\mathrm{Std})$ & $0,38(0,05-2,33)$ & $0,45(0,16-2,74)$ & $0,45(0,20-2,37)$ & $0,46(0,23-2,18)$ \\
Median $(\mathrm{min}-\mathrm{maks})$ & $184,57 \pm(313,234)$ & $13,77 \pm(71,197)$ & $135,37 \pm(85,171)$ & $123,72 \pm(63,716)$ \\
$\mathrm{LFG}\left(\mathrm{ml} / \mathrm{m} / 1,73 \mathrm{~m}^{2}\right)$ & $132(21,24-1606)$ & $134,69(18,07-286,79)$ & $128,33(20,89-401,5)$ & $119,7(34,62-263,04)$ \\
\hline NGALu $(\mathrm{ng} / \mathrm{ml})$ & $1294,94 \pm(5123,471)$ & $1524,03 \pm(5237,750)$ & $1901,35 \pm(4786,354)$ & $470,91 \pm(867,218)$ \\
Rerata $\pm(\mathrm{Std})$ & $25,5(3,90-24629,6)$ & $78,3(3,20-24098,4)$ & $60,3(4,8-17593,6)$ & $53,5(2,80-3189,6)$ \\
Median $(\mathrm{min}-$ maks $)$ & & & & \\
\hline
\end{tabular}

Keterangan: Data numerik disajikan dengan rerata, median, dan standar deviasi

Tabel 3. Analisis korelasi kadar NGALu dengan LFG pada variasi waktu

\begin{tabular}{lcc}
\hline Korelasi kadar NGALu dengan LFG & $\mathrm{r}$ & Nilai $\mathrm{p}$ \\
\hline 0 jam & $-0,384$ & 0,070 \\
12 jam & $-0,410$ & 0,052 \\
24 jam & $-0,668$ & $0,000^{* *}$ \\
48 jam & $-0,346$ & 0,106 \\
\hline
\end{tabular}

Keterangan: r: koefisien korelasi rank spearman

Nilai: $\geq 0,00-<0,20=$ korelasi sangat lemah; $\geq 0,20-<0,40=$ korelasi lemah; $\geq 0,40-<0,70=$ korelasi sedang; $\geq 0,70-<0,90=$ korelasi kuat; $\geq 0,90-<1,00=$ korelasi sangat kuat.

$\mathrm{p}=$ signifikansi $(p<0,05)$. Tanda $* *$ menunjukkan signifikan atau bermakna secara statistika

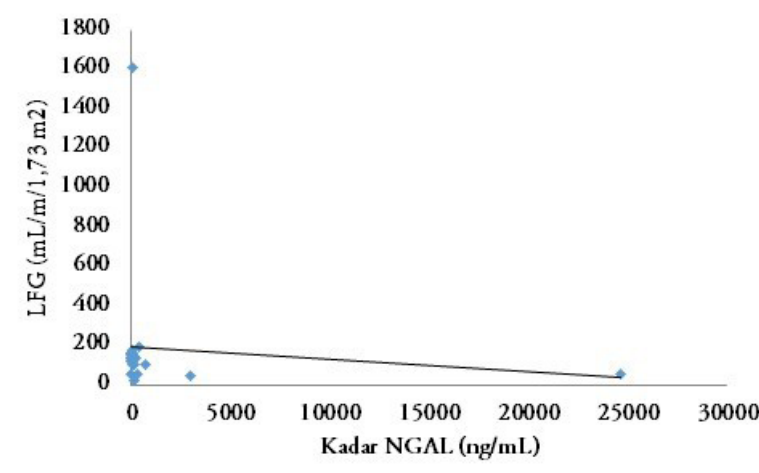

Variasi waktu jam ke-0

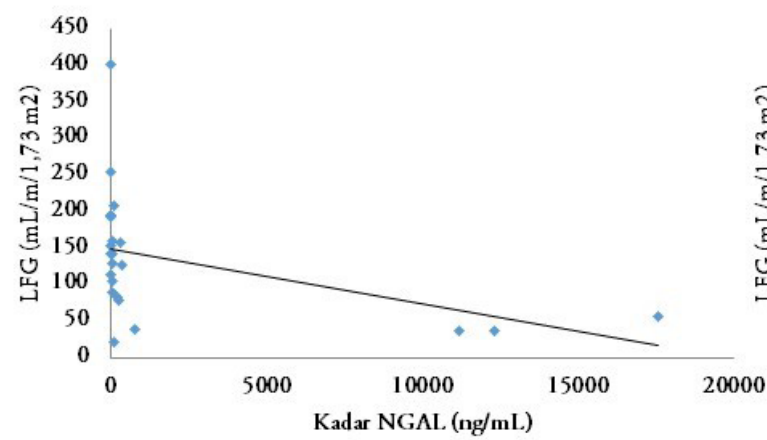

Variasi waktu jam ke-24
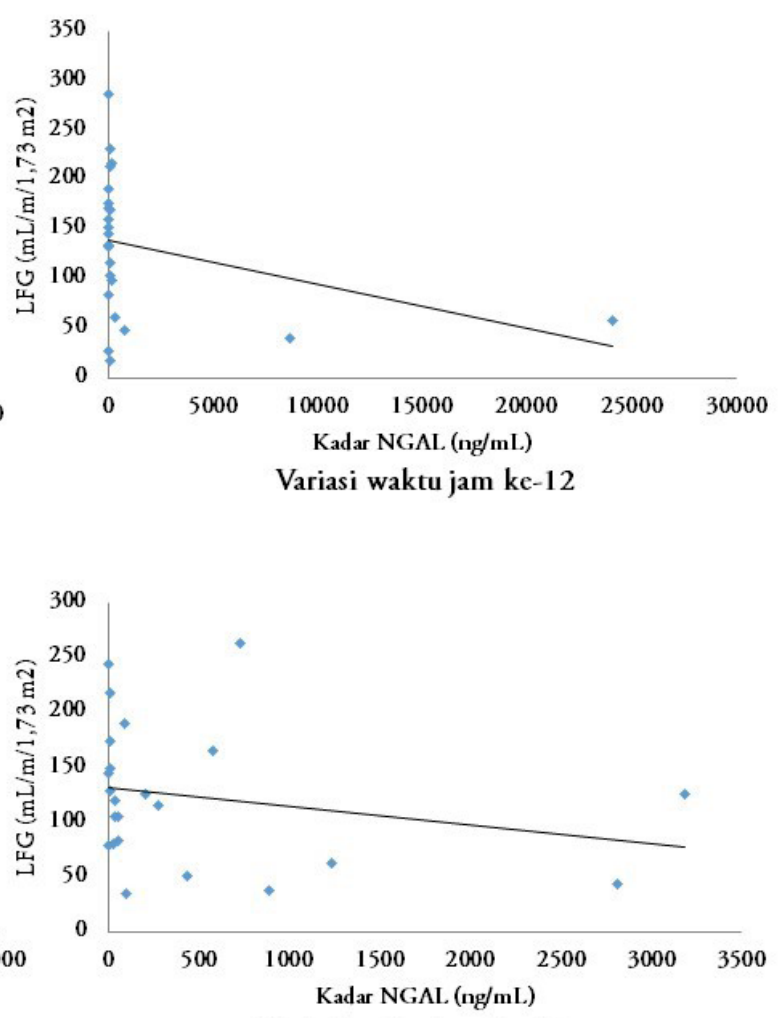

Variasi waktu jam ke-48

Gambar 1. Korelasi kadar NGALu dengan LFG pada variasi waktu jam ke-0, 12, 24, dan 48 


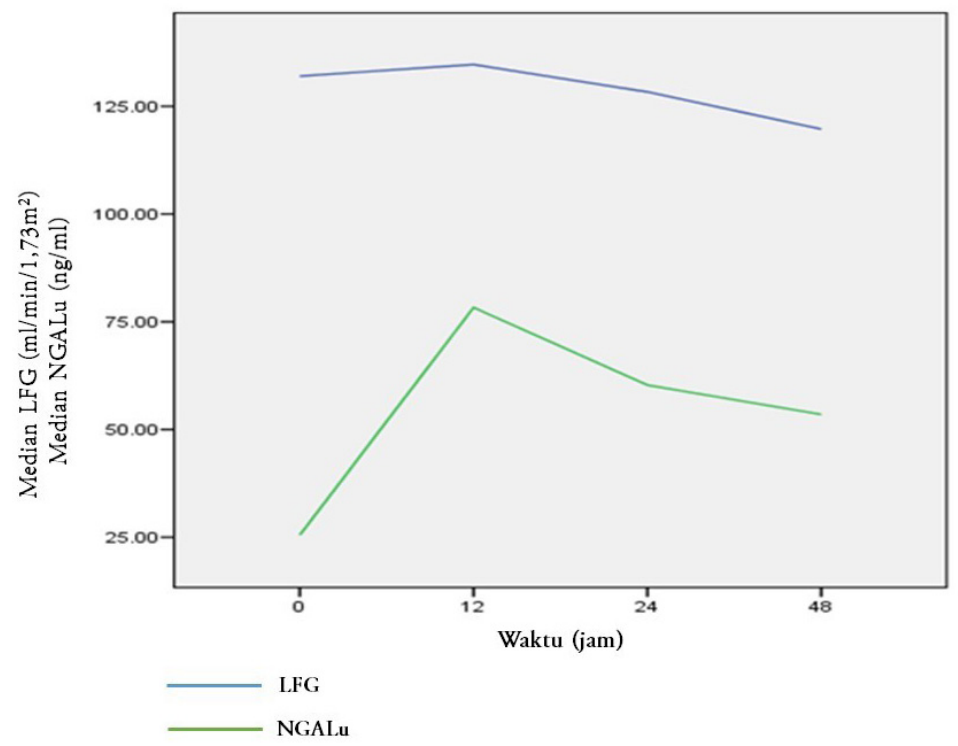

Gambar 2. Grafik kadar NGALu dan LFG pada variasi waktu jam ke-0, 12, 24 dan 48

12, 24, dan 48 pada anak sepsis. Hasil uji statistik menunjukkan adanya korelasi yang bermakna antara NGALu dengan LFG pada variasi waktu jam ke-24 dengan nilai $\mathrm{p}=0,000$ dan korelasi negatif sedang dengan $r=-0,668$. Korelasi negatif artinya jika NGALu naik maka nilai LFG turun begitu pula sebaliknya.

Gambar 2 merupakan grafik nilai median NGALu dan LFG pada variasi waktu jam ke-0, 12, 24, dan 48. Pada gambar terlihat puncak peningkatan kadar NGALu terjadi pada pengamatan jam ke-12 sejak terdiagnosis sepsis (median 78,30 ng/ml), sedangkan puncak penurunan LFG terjadi pada pengamatan jam ke-48 sejak terdiagnosis sepsis (median 119,70 $\mathrm{ml} / \mathrm{m} / 1,73 \mathrm{~m} 2$ ).

\section{Pembahasan}

Hasil penelitian ini menunjukkan korelasi yang bermakna antara kadar NGALu dan LFG pada anak sepsis dengan arah korelasi negatif. Hasil ini sesuai dengan penelitian yang dilakukan di RSHS pada tahun 2014. Hasil penelitian tersebut menyimpulkan terdapat korelasi negatif antara kadar NGALu dengan LFG yang diambil sewaktu pada anak sepsis berat dengan $\mathrm{r}=-0,550$ dan nilai $\mathrm{p}=0,001 .{ }^{18}$ Hasil penelitian yang dilakukan oleh Merrikhi ${ }^{19}$ dan Zapitelli ${ }^{16}$ menunjukkan adanya peningkatan NGALu sebagai penanda terjadinya gangguan ginjal akut pada anak sakit kritis.' Penelitian lain yang dilakukan terhadap 252 pasien anak yang datang ke unit gawat darurat menunjukkan kadar NGALu memiliki akurasi yang tepat dalam memprediksi timbulnya GgGA dibandingkan kreatinin serum dengan area under curve (AUC) 0,70-0,80. ${ }^{20}$

Pada penelitian kami dilakukan pemeriksaan kadar kreatinin, LFG dan NGALu pada variasi waktu jam ke-0, 12, 24, dan 48. Pada subjek didapatkan hasil kadar NGALu tertinggi pada pengamatan jam ke12, sedangkan penurunan kadar LFG terendah pada pengamatan jam ke-48. Hal tersebut sesuai dengan penelitian Mcllroy $^{21}$ yang dilakukan pada pasien pasca operasi jantung bypass. Mcllroy mendapatkan peningkatan kadar NGALu lebih cepat dibandingkan dengan peningkatan kreatinin yang menunjukkan adanya penurunan fungsi ginjal lebih dini. Penelitian kohort pada 140 anak sakit kritis juga menunjukkan kadar NGALu sebagai penanda dini GgGA meningkat lebih cepat ( 6 kali lipat daripada kontrol) pada 48 jam sebelum terjadi peningkatan kadar kreatinin serum. ${ }^{16}$ Bennet $^{22}$ melakukan penelitian prospektif dengan subjek anak yang menjalani operasi jantung. Bennet ${ }^{22}$ menemukan $51 \%$ dari 135 pasien mengalami GgGA berdasarkan peningkatan kadar rerata NGALu sebesar 15 kali lipat dalam 2 jam pasca operasi. Sementara diagnosis dengan menggunakan kreatinin serum baru muncul setelah 2-3 hari pasca operasi. Penelitian lain juga menyimpulkan berdasarkan penelitian Mishra (71 
anak pasca operasi jantung bypass), Hirsch (91 anak yang mendapat keteterisasi jantung dan angiografi kontras), serta Trachtman (34 anak dengan sindrom hemolitik uremik) menunjukkan terjadi peningkatan kadar NGALu yang berperan sebagai penanda dini timbulnya GgGA bila dibandingkan dengan kreatinin serum. $^{23}$

Hasil persamaan analisis regresi pada variasi waktu didapatkan kadar NGALu dan LFG memiliki korelasi negatif sedang pada jam ke-24. Puncak peningkatan kadar NGALu terjadi pada jam ke-12 dengan nilai $78,30 \mathrm{ng} / \mathrm{ml}$, lebih dini dibandingkan korelasi dengan LFG sehingga diharapkan tata laksana GgGA yang lebih tepat mampu dilakukan lebih awal untuk mengurangi mortalitas dan morbiditas anak sepsis. Hasil ini sesuai dengan penelitian pada tahun 20102014 yang menyimpulkan bahwa puncak peningkatan kadar NGALu terjadi pada jam ke-6 sampai 12 dengan nilai NGALu $>126 \mathrm{ng} / \mathrm{ml}$ dapat mendeteksi GgGA. ${ }^{17}$ Penelitian Zappitelli tahun 2007 menyimpulkan kadar NGALu 20,9 $\pm 28,1 / 11,6(27,5) \mathrm{ng} / \mathrm{ml}$ menunjukkan adanya GgGA. ${ }^{16}$ Penelitian yang dilakukan di Iran pada tahun 2012 terhadap pasien anak yang dirawat di PICU menyimpulkan nilai optimum NGALu untuk mendeteksi GgGA pada hari perawatan ke-1 hingga ke-3 adalah $65,82 \mathrm{ng} / \mathrm{ml}-66,81 \mathrm{ng} / \mathrm{ml} .{ }^{19}$

Keterbatasan penelitian ini adalah penyebab sepsis tidak homogen dan derajat sepsis pada subjek tidak sama. Keterbatasan lain adalah pada keadaan normal NGAL dikeluarkan dalam konsentrasi yang sangat rendah dari beberapa jaringan tubuh selain organ ginjal.

\section{Kesimpulan}

Terdapat korelasi negatif sedang antara kadar NGALu dengan LFG pada variasi waktu jam ke-24 untuk mendeteksi dini GgGA pada anak sepsis.

\section{Daftar pustaka}

1. UNICEF. Levels\&trends in child mortality. UNICEF.2015 Diunduh pada Oktober 2018. Didapat dari:http://www.who. int/maternal_child_adolescent/documents/levels_trends_child_ mortality_2015/en/.

2. Hartman M, Linde-Zwirble W, Angus D, Watson R. Trends in the epidemiology of pediatric severe sepsis. PCCM J 2013;14:686-93.
3. Latief A, Chairulfatah A, Alam A, Pudjiadi A, Maldsie R, Hadinegoro S. Diagnosis dan tata laksana sepsis pada anak. Jakarta: Ikatan Dokter Anak Indonesia; 2016.

4. Singer M, Deutschman C, Seymour C, Shankar-Hari M, Annane D, Bauer M. The third international consensus definitions for sepsis and septic shock (sepsis-3). JAMA 2016;315:801-10.

5. Bradshaw C, Goodman I, Rosenberg R, Bandera C, Fierman A, Rudy B. Implementation of an inpatient pediatric sepsis identification pathway. AAP News \& Journals 2016;137:1-10.

6. Gomez H, Kellum JA. Sepsis-induced acute kidney injury. Curr Opin Crit Care 2016;22:546-53.

7. Racmadi D, Sekarwana N, Hilmanto D, Garna H, Penyunting. Buku ajar nefrologi anak. Edisi ke-3. Jakarta: Ikatan Dokter Anak Indonesia; 2017.

8. Srinivasa S, Reshmavathi V. Incidence and etiology of acute kidney injury in children admitted to PICU using pRIFLE criteria. Curr Pediatr Res 2016;20:518-26.

9. Hooman N, Nakhaii S, Sharif M. Update on acute kidney injury in pediatric-part 1. J Pediatr Nephrol 2014;2:56-62.

10. Perkumpulan Nefrologi Indonesia (PERNEFRI) Dinas Kesehatan. 7 th report of indonesian renal registry 2014. Jakarta: Dinas Kesehatan; 2014.

11. Alhaddad O, Alsebaey A, Amer M, El-Said H, Salman T. Neutrophil gelatinase assosiated lipocalin: a new marker of renal function in c-related end stage liver disease. Gastroenterol Res Pract2015;1-7.

12. Fodor R, Grigorescu B, Veres M, Orlandea M, Badea J, Hlavathy K. Plasma neutrophil gelatinase-assosiated lipocalin (NGAL)- early biomarker for acute kidney injury in critically ill patients. J Crit Care MedS 2015;1:154-61.

13. Martensson J, Bellomo R. The rise and fall of NGAL in acute kidney injury. Blood Purif 2014;37:304-10.

14. Angeletti S, Fogolari M, Morolla D, Capone F, Costantino $S$, Spoto S. Role of neutrophil gelatinase-assosiated lipocalin in the diagnosis and early treatment of acute kidney injury a case series af patients with acute decompesated heart faillure: a case series. Cardiol Res Pract 2015;1-7.

15. Bagshaw S, Bennet M, Haase M, Haase-Feilitz A, Egi M, Morimatsu H. Plasma and urine neutrophil gelatinaseassociated lipocalin in septic versus non septic acute kidney injury in critical illness. Intensive Care Med 2010;36:452-61.

16. Zappitelli M, Kimberly K, Arikan A, Loftis L, Ma Q, Devarajan P. Urine neutrophil gelatinase-associated lipocalin is an early marker of acute kidney injury in critically ill children: a prospective cohort study. Crit care 2007;11:1-11.

17. Zwiers A, De Wildt S, Rosmalen J, Rijke Y, Bujis E, Tibboel B. Urinary neutrophil gelatinase-associated lipocalin identifies critically ill young children with acute kidney injury following 
intensive care admission: a prospective cohort study. Crit Care 2015;19:181-95.

18. Wibowo B. Korelasi antara kadar urine neutrophil gelatinase associated lipocaline (uNGAL) dengan laju filtrasi glomerolus pada pasien anak sepsis berat, (tesis). Bandung: Fakultas Kedokteran Universitas Padjadjaran, 2014.

19. Merrikhi A, Gheissari A, Mousazadeh H. Urine and serum neutrophil gelatinase- associated lipocalin cut off point for the prediction of acute kidney injury. Adv Biomed Res 2014;3:66.

20. Du Y, Zapitelli M, Mian A, Bennet M, Ma Q, Devarajan P. Urinary biomarkers to detect acute kidney injury in the pediatric emergency center. Pediatr Nephrol 2011;26:267-74.

21. Mcllroy D, Wagener G, Lee T. Biomarkers of Acute Kidney Injury. Anestesiology 2011;112:998-1004.

22. Bennet M, Dent, Ma Q, Dastrala, Grenier W. Urine NGAL predics severity of acute kidnet injury after cardiac surgery: a prospective study. Clin J Am Soc Nephrol 2008;3:665-73.

23. Bolignano D, Donato V, Coppolino G, Campo S, Buemi A, Lacquaniti A. Neutrophil gelatinase associated lipocalin (NGAL) as a marker of kidney damage. Am J Kidney Dis 2008;25:595-602. 